\title{
EFFECT OF USING SOME FEED ADDITIVES (TW- PROBIOTICS) IN DAIRY COW RATIONS ON PRODUCTION AND REPRODUCTIVE PERFORMANCE
}

\author{
T.H. Mostafa, F.A. Elsayed, M.A. Ahmed and M.A. Elkholany
}

\author{
Animal Production Research Institute, Agriculture Research Center, Ministry of Agriculture, \\ Egypt
}

\section{SUMMARY}

This study aimed to evaluate the effects of supplementing commercial yeast culture (S. cerevisiae) namely $B G Y 35$ or a product of lactic acid bacteria and enzymes namely AVI-BAC@ to the diet of lactating crossbred cows, for the last 2 months pre-partum and the first 4 months post-partum (from July to October), on body weight, feed and water intakes, milk production, some blood parameters, reproductive performance and physiological response. A total of 12 cows with average live body weight (LBW) of $440 \mathrm{~kg}$ and 2-6 parities, were used in this study. Cows were divided into three groups, 4 animals in each group. During pre- and post-partum period, cows in the $1^{\text {st }}$ group (G1) were fed the control diet (untreated), while those in the $2^{\text {nd }}(G 2)$ and $3^{\text {rd }}(G 3)$ groups were fed the control diet daily supplemented with $3 \mathrm{~g} A V I-B A C / c o w$ and $20 \mathrm{~g} B G Y 35 / \mathrm{cow}$, respectively. During pre- and post-partum, $L B W$, feed and water intakes, rectal temperature (RT), respiration rate $(R R)$ and pulse rate $(P R)$, yield and composition of milk were recorded. Blood samples were collected for determination of total proteins $(T P)$, albumin $(A L)$, creatinine, urea and glucose concentrations in serum. Activity of transaminases (AST and ALT) and alkaline phosphatase (ALP) as well as concentrations of thyroid hormones (T3 and T4), estradiol (E2) and progesterone (P4) were also determined in blood serum. Post-partum $1^{\text {st }}$ estrous interval (PPFEI), number of services/conception (NSC), days open (DO) and conception rate (CR) were calculated. Results showed insignificant effect of probiotics supplementation on LBW of cows during prepartum, calving and post-partum as well as on birth weight of produced calves. During pre-partum, both probiotics supplementations increased $(P<0.05)$ feed intake of rice straw $(R S)$ and total $D M$ relative to $L B W$. Intakes from concentrate feed mixture (CFM), corn silage (CS), total DM/h or total DM relative to metabolic body weight were not affected. During post-partum period, probiotics supplementation increased $(P<0.05) R S$ and total DM intakes. Total DM intake relative to LBW or metabolic body weight was not affected. There was insignificant effect of probiotics supplementation on milk yield and milk composition, although average daily milk yield tended to increase by about 17 and $15 \%$ and all milk components increased for G2 and G3 as compared to G1. During pre-partum period, concentrations of all blood biochemicals were not affected by probiotics supplementation. During post-partum, only serum $A L$ concentration was increased $(P<0.05)$ in both supplemented groups as compared to the control one. Activities of AST, ALT and ALP were not affected by probiotics supplementation during pre- and post-partum periods. There was a reduction $(P<0.05)$ in T4 concentration in G2 during pre-partum, and reduction $(P<0.05)$ in T3 and T4 concentrations in both supplemented groups as compared to the control group during post-partum period. Within 120 days postpartum, PPFSI was earlier by about 21.5 and $25 d$, NSC was less by about 0.5 and 0.75 and DO was shorter by about 21.0 and $36.5 d$ in $G 2$ and $G 3$ than in G1. The CR was higher in G3 (100\%) than in G2 and $G 1(50 \%$ in each). Probiotics supplementation resulted in slight reduction in $R R, R T$ and PR of cows during pre- and postpartum periods as compared to un-supplemented diet, but the differences were not significant. Both probiotics supplementation decreased water consumption as compared to control diet, but the differences were significant $(P<0.05)$ only between $G 2$ and $G 1$.

In conclusion, dietary supplementation of probiotics AVI-BAC $(3 \mathrm{~g} / \mathrm{h} / \mathrm{d})$ to diet of dairy cows, during 2 months pre-partum and 4 months post-partum, seemed to have a beneficial effect on milk yield and fat yield, while BGY $35(20 \mathrm{~g} / \mathrm{h} / \mathrm{d})$ seemed to have pronounced improvement on reproductive performance of dairy cows in terms of increasing conception rate and shortening days open.

Keywords: dairy cow, additives, Tw- probiotics, enzymes, production, reproductive.

\section{INTRODUCTION}

The growth promoters are substances when fed to animals improve their production performance parameters. The growth promoter substances include antibiotic growth promoters as flavomycin, probiotics, acidifers, enzymes, herbal products, beta agonists, microflora enhancer and immunomodulators (Devegowda, 1996). Probiotics are described as live microbial feed supplements (Fuller, (1989) in a mono or mixed culture of living microorganisms (Havenaar et al., 1992) in group of microorganism strains (Fooks and Gibson, 2002) based on Lactobacillus, Bacillus and Saccharomyces (Burns, 1995), which beneficially affects the host animal by improving its microbial balance and properties of the indigenous microflora.

Interest in the use of direct-fed microbials as feed supplements for dairy cows had a great attention in recent years. Yeast cultures (YC) are frequently used as additives in diets of dairy cows. Inclusion of YC in diets of ruminants and non-ruminants leads to improve healthy status and productivity of animals (Calsamiglia et al., 2006). Results on performance 
results of ruminants fed YC products have been variable. Improvements in dry matter intake, DMI (Wohlt et al., 1991 and 1998), milk production and components (Piva et al., 1993), and reproductive performance (Abdel-Khalek, 2003) have been noted when cows were fed YC. In contrast, no differences were found in DMI (Piva et al., 1993), milk production and composition (Robinson and Garrett, 1999) in other studies when cows were fed YC.

AVI-BAC as probiotic is derived from fermentation processes using micro-organisms such as bacteria (Lactobacillus and Bifidobacterium), and fungi. It is manufactured from Aspergillus SP. Published Literature regarding the use of AVI-BAC has been demonstrated for poultry and growing animals (Sretenović1 et al., 2008).

Generally, supplemented probiotics (YC) may be most beneficial to dairy cows if it is fed before parturition, a period that is characterized by decreased DMI as parturition approaches, and through peak of lactation (Wohlt et al., 1991). Therefore, the objectives of the current study were to determine the effects of supplementing commercial yeast culture (S. cerevisiae) namely BGY 35 or a product of lactic acid bacteria and enzymes namely AVI-BAC® to the diet of lactating crossbred cows for the last 2 months pre-partum and the first 4 months postpartum on feed and water intakes, milk yield, milk composition, some blood parameters, reproductive performance and physiological response.

\section{MATERIALS AND METHODS}

The study was conducted at the Animal Production Research Station, El-Serow, belonging to Animal Production Research Institute, Agricultural Research Center.

\section{Animals:}

A total of 12 crossbred cows (Baladi x Friesian) within the last two months of pregnancy, with an average live body weight of $440 \pm 26.434 \mathrm{~kg}$ and $2^{\text {nd }}$ to $6^{\text {th }}$ parities, were used in this study. The experimental cows were divided according to LBW, parity and milk production to three experimental groups, four animals in each group. Animal were housed under semi-open shed. Also, LBW of calves produced from each group was recorded and then weight gain was calculated during post-natal period

\section{Feeding system:}

During pre- and post-partum period, cows in all groups were fed a diet composed of concentrate feed mixture (CFM), corn silage (CS) and berseem hay (BH). Rice straw (RS) was offered ad lib. The CFM consisted of $33 \%$ wheat bran, $28 \%$ yellow corn, $34 \%$ uncorticated cotton seed meal, $3 \%$ molasses, $1.5 \%$ premix and $0.5 \%$ common salt. Chemical analysis of CFM, CS, BH and RS are shown in Table (1).

\begin{tabular}{lcccc} 
Table 1. Chemical analysis (\% on DM basis) of different feed stuffs of the control diet & \\
\hline Nutrient & CFM & CS & BH & RS \\
\hline DM (\%) & 90.0 & 35.50 & 89.0 & 89.0 \\
OM & 93.65 & 90.90 & 87.70 & 86.97 \\
CF & 15.03 & 30.50 & 30.50 & 38.50 \\
CP & 15.45 & 9.51 & 11.30 & 3.23 \\
EE & 3.40 & 3.15 & 3.20 & 1.55 \\
NFE & 59.77 & 47.74 & 37.70 & 43.69 \\
Ash & 6.35 & 9.10 & 12.3 & 13.03 \\
\hline
\end{tabular}

CFM: Concentrate feed mixture. BH: Berseem hay. CS: Corn silage. RS: Rice straw.

Cows in the $1^{\text {st }}$ group were fed the control diet (untreated), while those in the $2^{\text {nd }}$ and $3^{\text {rd }}$ groups were fed the control diet daily supplemented with $3 \mathrm{~g}$ AVIBAC/cow (AVI-BAC) and $20 \mathrm{~g}$ BGY 35/cow (BGY $35)$, respectively. Supplements of each treatment group were well mixed with the ingredients of daily amount of CFM immediately before feeding. Feeds were offered to animals in all groups twice daily for 2 months pre- and 4 months post-partum period). Cows in all groups were individually fed on different experimental diets and water was individually offered three times/day with daily recording of water consumption.

Cows in all groups were fed based on milk yield according to (NRC, 1988). Amount of feeds were adjusted biweekly based on milk yield and reproductive status.

Yeast culture (BGY 35) is a brewer's dried yeast (Saccharomyces cerevisiae) composed of $35 \%$ crude protein, $1 \%$ crude fat and $8 \%$ crude fiber, and contains vitamins, amino acids and minerals.
However, probiotic (AVI-BAC@) as growth promoter was produced by ProByn International Inc (USA). Each kg of AVI-BAC contains lactobacillus (100 g L. acidophilus, $1.0 \times 10^{8} \mathrm{CFU} / \mathrm{g}$ and $L$. planterum, $98 \mathrm{~g}, 9.8 \times 10^{7} / \mathrm{g}$ ), Bifidobactrium bifidum (2 g, $\left.2.0 \times 10^{6} / \mathrm{g}\right)$, Bacillus subtilis fermentation extract $(50 \mathrm{~g})$, Asperagillus oryzae fermentation extract $(50 \mathrm{~g})$, dextrose as diluents $(700 \mathrm{~g})$ and enzymes including amylase $(25 \mathrm{U} / \mathrm{g})$, cellulose $(4.5$ $\mathrm{U} / \mathrm{g})$, beta-glucanase $(2.25 \mathrm{U} / \mathrm{g})$ and hemicellulase (2.75 U/g).

The ambient temperature during the entire length of the experimental period ranged between 23 to $40 \mathrm{C}^{\circ}$.

\section{Experimental procedures:}

Body temperature, respiration rate and pulse rate:

During pre- and post-partum, body temperatures including rectal (RT) using digital precision thermometer (TRD, Ellab Cropcopen Hagen, Denmark) were recorded at 12:00 h. At the same 
time, respiration rate (RR) was measured by counting the flank movements for one minute using a stop watch. Pulse rate of the tail vein was also recorded.

\section{Body weight, feed intake and water consumption:}

At the start of the experimental period ( 2 months pre-partum), experimental cows in all groups were weighed to get the initial LBW, and then animals were weighed during post-partum. After calving, calves of each group were weighed.

Average daily feed intake and water consumption was individually recorded during pre- and postpartum periods.

\section{Milking and milk samples:}

Milk yield was measured after the calves were allowed to suckle colostrums from their dams for the first seven days. Cows were milked by milking machine twice daily at 5 a.m. and 4 p.m. After each milking, milk was weighed on limited day for each week for all lactation period. Milk samples of each animal (mixture from morning and evening milking) were taken during mid-lactation period for the determination of milk composition.

\section{Chemical analysis:}

Chemical analysis of feeds was determined after the official methods of AOAC (1980), while chemical analysis of milk was determined using milko-Scan (Model 133 B).

\section{Blood sampling:}

Animals in each experimental group were bled on two weeks period pre- and one month post-partum. Bleeding was done before morning feeding from each animal by jugular vein-puncture into test-tubes. Blood was allowed to clot and the serum was separated. Seraum samples were stored in deep freezer $(-20 \circ \mathrm{C})$ before being analyzed for total proteins (Gornal et al., 1949), albumin (Doumas and Theodore Peters, 2009), creatinine (Bartles et al., 1972), urea (Fawcett and Soctt, 1960) and glucose (Trinder, 1969). Also, activities of asprtate (AST), alanine (ALT) transaminases (Murray, 1984) and alkaline phosphatase (ALP, Belfieid and Goldberg, $1971)$ as well as thyroid hormone $\left(\mathrm{T}_{4}\right)$ concentration, triiodithyronine $\quad\left(\mathrm{T}_{3}, \quad\right.$ Sterling, 1975), tetraiodothyronine (thyroxin, T4, Liewendahl, 1990), estradiol (E2, Batzer, 1980) and progesterone (P4, Boganic et al., 1991) were also determined in blood serum. However, concentration of globulin was computed. Blood biochemicals were determined using spectrophotometer and commercial kits.

\section{Reproductive measurements:}

Natural insemination was used as a method of breeding in the station under the current study for all cows in heat 50 days post-parturition. For each cow, the date of service was recorded and thereafter followed up for estrus return 21 days later. The nonreturn animals were rectally examined 50 to 60 days after the first breeding for pregnancy diagnosis and in any doubtful case, the examination was repeated 2 weeks later.
During post-partum period, interval from calving to $1^{\text {st }}$ service (PPFSI) or to conception (days open) and number of services per conception were recorded. Also, conception rate within 120 daypostpartum period was recorded.

\section{Statistical analysis:}

Statistical analysis was done using the General Linear Model (GLM) procedures of the statistical Analysis Systems (SAS, 2002). . Data obtained were tested by analysis of variance with one way design to test the group differences according to the following model:

Yij $=\mu+A i+$ eij; where $:$ Yij= observed values, $\mu=$ overall mean, $\mathrm{Ai}=$ experimental group) and $\mathrm{eij}=$ Random error. Values were given as mean \pm standard error. All statements of significance were based on $\mathrm{P}<0.05$ using Duncan Multiple Range Test within the computer program.

\section{RESULTS AND DISCUSSION}

\section{Live body weights:}

Results presented in Table (2) show insignificant effect of dietary supplementation of the two probiotics on live body weight (LBW) of cow in different experimental groups during pre-partum, calving and post-partum as well as on birth weight of produced calves. Supplementation with the two probiotics did not affect pre- or post-partum or prepartum body weight. This is partially in agreement with the results of Dann et al. (2000) who reported that initial body condition score (BCS) of cows was not affected when cows were fed a diet supplemented with YC. Also, Abdel-Khalek (2003) found that YeaSacc supplementation as YC fed to primi- and multiparous Friesian cows had no significant effect on birth weight of calves. In addition, Ahmed et al. (2008) showed insignificant effect of bacterial feed additive (Lecture) on LBW of Zaraibi goat does during late pregnancy and lactation period.

\section{Feed intake:}

Results regarding feed intake as dry matter (DM) during pre-partum period (Table 3) show significant $(\mathrm{P}<0.05)$ increase in feed intake from rice straw $(\mathrm{RS}$, which was allowed ad libitum for cows in all groups) of cows fed diet supplemented with probiotics (AVI$\mathrm{BAC}$ and $\mathrm{BGY}$ ) as compared to the control diet. This increase did not affect total DM intake, because cows in all groups were fed on similar amounts of concentrate feed mixture (CFM) and corn silage (CS). However, the observed increase DM intake from RS resulted in a significant $(\mathrm{P}<0.05)$ increase in total DM intake relative to LBW and insignificantly relative to metabolic body weight.

During post-partum period (lactation period), feed intake from RS was also significantly $(\mathrm{P}<0.05)$ increased in treated groups (AVI-BAC and BGY) as compared to the control. This increase led to a significant $(\mathrm{P}<0.05)$ increase in total $\mathrm{DM}$ intake without significant effect on total DM intake relative to LBW or metabolic body weight (Table 3). 
Table 2. Effect of dietary supplementation of probiotics $(\mathrm{X} \pm \mathrm{S}$.E) on live body weight (LBW) of cows at pre- and post-partum periods and of produced calves at calving

\begin{tabular}{lccc}
\multicolumn{1}{c}{ Item } & Control & AVI-BAC & BGY35 \\
\hline Average LBW of cows (kg): & & & \\
Two months pre-partum & $440.00 \pm 28.284$ & $437.00 \pm 33.558$ & $434.75 \pm 16.007$ \\
One month pre-partum & $455.00 \pm 28.104$ & $452.75 \pm 34.376$ & $450.25 \pm 15.548$ \\
At calving & $513.25 \pm 28.412$ & $506.50 \pm 37.728$ & $490.00 \pm 12.227$ \\
Post-calving & $445.00 \pm 32.275$ & $435.00 \pm 35.355$ & $435.25 \pm 14.979$ \\
One month post-partum & $456.75 \pm 31.579$ & $448.50 \pm 32.116$ & $449.50 \pm 12.073$ \\
Average LBW of calves (kg): & & & $29.50 \pm 0.957$ \\
At calving & $28.75 \pm 3.146$ & &
\end{tabular}

Table 3. Effect of dietary supplementation of probiotics $(\mathrm{X} \pm \mathrm{S}$.E) on feed intake of cows during pre- and post-partum periods

\begin{tabular}{lccc}
\hline Feed intake & Control & AVI-BAC & BGY35 \\
\hline During pre-partum period: & & & \\
CFM (kg DM/h/d) & $4.50 \pm 0.000$ & $4.50 \pm 0.000$ & $4.50 \pm 0.000$ \\
RS (kg DM/h/d) & $1.69 \pm 0.005^{\mathrm{b}}$ & $1.75 \pm 0.010^{\mathrm{a}}$ & $1.77 \pm 0.010^{\mathrm{a}}$ \\
CS (kg DM/h/d) & $2.75 \pm 0.000$ & $2.75 \pm 0.000$ & $2.75 \pm .000$ \\
Total DM intake (kg DM/h/d) & $8.94 \pm 0.005$ & $9.00 \pm 0.010$ & $9.02 \pm 0.010$ \\
Total DM intake (\% of LBW) & $1.87 \pm 0.123^{\mathrm{b}}$ & $1.97 \pm 0.154^{\mathrm{a}}$ & $1.93 \pm 0.0682^{\mathrm{a}}$ \\
Total DM intake (g/kg W $\left.{ }^{0.75}\right)$ & $87.60 \pm 4.125$ & $89.97 \pm 5.356$ & $89.75 \pm 2.375$ \\
During post-partum period (kg/h): & & & \\
CFM (kg DM/h/d) & $4.95 \pm 0.000$ & $4.95 \pm 0.000$ & $4.95 \pm 0.000$ \\
RS (kg DM/h/d) & $1.68 \pm 0.027^{\mathrm{b}}$ & $1.77 \pm 0.008^{\mathrm{a}}$ & $1.78 \pm 0.000^{\mathrm{a}}$ \\
CS (kg DM/h/d) & $3.33 \pm 0.000$ & $3.33 \pm 0.000$ & $3.33 \pm 0.000$ \\
Total DM intake (kg DM/h/d) & $9.96 \pm 0.027^{\mathrm{b}}$ & $10.05 \pm 0.008^{\mathrm{a}}$ & $10.06 \pm 0.000^{\mathrm{a}}$ \\
Total DM intake (\% of LBW & $2.24 \pm 0.169$ & $2.31 \pm 0.187$ & $2.29 \pm 0.050$ \\
Total DM intake (g/kg W ${ }^{0.75}$ ) & $102.908 \pm 5.694$ & $105.613 \pm 6.298$ & $104.76 \pm 1.734$ \\
\hline
\end{tabular}

$\mathrm{a}$ and $\mathrm{b}$ : Means having different superscripts within the same row are significantly different at $\mathrm{P}<0.05$.

In agreement with the present results, some authors observed an improvement in DM intake when lactating cows were fed YC (Williams et al., 1991; Wohlt et al., 1991 and 1998; Robinson and Garrett, 1999; Dann et al., 2000). In addition, similar results were reported on lactating buffaloes fed Biovet as micro-organisms added to their diets (Gujjar et al., 2006) or dairy goats fed Lecture as a bacterial feed additive (Ahmed et al., 2008). However, Aikman et al. (2008) observed no difference in DM intake between the control and treated cows fed two TMR's differing in level of concentrate and supplemented with direct-fed microbial (DFM) during the first 14 weeks of lactation. The significant increase in DM intake from $\mathrm{RS}$ may reflect higher ruminal fermentation in treated groups than in control. Feeding yeast products may be most beneficial to dairy cows during late gestation and early lactation because of their effects on rumen fermentation and nutrients digestion (Dann et al., 2000) in term of increasing the digestibility of CP and ADF (Wohlt et al., 1998). The most cited benefit of yeast cultures on ruminal digestion is support of the growth and activity of anaerobic, namely cellulolytic bacteria. Yeasts would utilize residual oxygen introduced into the rumen with feeds, thus contributing to maintain anaerobic environment (Calsamiglia et al., 2006). On the other hand, applying of the complex lactic acid bacteria improved fermentation quality and in vitro DM digestibility (Yongkai et al., 2012).

\section{Milk production:}

Results shown in Table (4) revealed insignificant effect of dietary supplementation of probiotics on milk yield and milk composition of cows, although cows in both treatment groups increased their average daily milk yield by about 17 and $15 \%$ for AVI-BAC and BGY groups as compared to the control cows, respectively. Also, dietary supplementation of both probiotics insignificantly increased milk components including fat, protein and lactose as compared to the control diet. These results indicated higher fat, protein and lactose yields in milk of cows in the treatment groups than in controls. It is of interest to record that the observed increase in milk yield and milk component percents of treated groups compared with the control one was associated with increase in DM intake of RS (Table 3). Similarly, Soder and Holden (1999) found no effects of YC on DM intake or milk yield and composition of primi-parous and multi-parous cows. Consequently, the effects of YC supplementation during the pre-partum period and through peak lactation remain controversial and have not been adequately researched. 
Table 4. Effect of dietary supplementation of probiotics $(\mathrm{X} \pm \mathrm{S} . \mathrm{E})$ on average daily milk yield and chemical composition of milk produced by cows during lactation period

\begin{tabular}{lccc}
\hline \multicolumn{1}{c}{ Item } & Control & AVI-BAC & BGY35 \\
\hline Average daily milk yield (kg) & $8.055 \pm 0.850$ & $9.430 \pm 0.548$ & $9.260 \pm 0.752$ \\
Milk composition (\%): & & & \\
Fat & $3.603 \pm 0.199$ & $4.003 \pm 0.150$ & $3.830 \pm 0.158$ \\
Protein & $2.595 \pm 0.063$ & $2.748 \pm 0.034$ & $2.773 \pm 0.114$ \\
Lactose & $4.595 \pm 0.105$ & $4.838 \pm 0.080$ & $4.885 \pm 0.048$ \\
Solids not fat & $7.883 \pm 0.158$ & $8.293 \pm 0.106$ & $8.355 \pm 0.136$ \\
Total solids & $11.480 \pm 0.115$ & $12.288 \pm 0.196$ & $12.178 \pm 0.115$ \\
Ash & $0.710 \pm 0.003$ & $0.704 \pm 0.005$ & $0.706 \pm 0.005$ \\
\hline
\end{tabular}

All differences among groups are not significant.

Table 5. Effect of dietary supplementation of probiotics $(\mathrm{X} \pm \mathrm{S}$.E) on some biochemicals in blood serum of cows during pre- and post-partum periods

\begin{tabular}{lccc}
\hline \multicolumn{1}{c}{ Item } & Control & AVI-BAC & BGY35 \\
\hline During pre-partum period: & & & \\
Total protein (g/dl) & $7.391 \pm 0.310$ & $6.504 \pm 0.111$ & $7.697 \pm 1.017$ \\
Albumin (g/dl) & $2.891 \pm 0.091$ & $3.641 \pm 0.279$ & $3.486 \pm 0.254$ \\
Globulin (g/dl) & $4.500 \pm 0.254$ & $2.863 \pm 0.325$ & $4.211 \pm 0.876$ \\
Creatinine (mg/dl) & $1.030 \pm 0.091$ & $0.837 \pm 0.039$ & $0.899 \pm 0.104$ \\
Urea-N (mg/dl) & $20.969 \pm 1.615$ & $26.099 \pm 7.935$ & $21.893 \pm 4.883$ \\
Glucose (mg/dl) & $83.29 \pm 1.028$ & $81.91 \pm 0.348$ & $82.56 \pm 0.188$ \\
During post-partum period: & & & \\
Total protein (g/dl) & $7.419 \pm 0.403$ & $8.013 \pm 0.781$ & $6.532 \pm 0.229$ \\
Albumin (g/dl) & $2.677 \pm 0.136^{\mathrm{b}}$ & $3.368 \pm 0.075^{\mathrm{a}}$ & $3.384 \pm 0.077^{\mathrm{a}}$ \\
Globulin $(\mathrm{g} / \mathrm{dl})$ & $4.742 \pm 0.391$ & $4.645 \pm 0.854$ & $3.148 \pm 0.216$ \\
Creatinine (mg/dl) & $0.987 \pm 0.072$ & $0.879 \pm 0.081$ & $0.790 \pm 0.038$ \\
Urea-N (mg/dl) & $16.794 \pm 0.530$ & $14.978 \pm 1.357$ & $17.113 \pm 1.053$ \\
Glucose (mg/dl) & $73.71 \pm 0.311$ & $74.15 \pm 0.195$ & $74.47 \pm 0.169$ \\
\hline
\end{tabular}

$\mathrm{a}$ and $\mathrm{b}$ : Means having different superscripts within the same row are significantly different at $\mathrm{P}<0.05$.

In accordance with the present results of YC, Robinson and Garrett (1999) did not observe any beneficial effects of yeast cultures on the milk production and its composition in dairy cows. However, improvements in milk components have been noted when cows were fed YC (Piva et al., 1993). In this respect, Wohlt et al. (1991) observed that primi-parous Holstein cows fed YC starting $30 \mathrm{~d}$ pre-partum and continuing through wk 18 of lactation had greater milk yield through 18 wk lactation period. In a similar study, Wohlt et al. (1998) found that YC supplementation during early lactation improved milk yield. In a subsequent study, Robinson and Garrett (1999) observed trends for increased DM intake and milk production during early lactation for cows fed YC pre- and postpartum. Similar results were reported by Dann et al. (2000). However, Swartz et al. (1994) reported that daily supplementation of two yeast culture preparations (Saccharomyces cerevisiae, at about 5 x [10.sup.10] cfu/d per cow) did not significantly improve the production parameters of lactating dairy cows under the nutritional management programs of the farms.

The obtained results of cows fed AVI-BACK, Aikman et al. (2008) did not observe a positive response in milk production, and fat and protein percentages in milk of cows fed diet supplemented with DFM as compared to the control cows. Similar full lactation results were reported by others when Holstein cows were fed lucerne maize based diets (Krause et al., 2002). Also, Hagg and Henning
(2007) reported no difference in milk fat percentage when cows were fed DFM as compared to control cows. However, Biovet as a DFM has favorable effect on milk yield and feed efficiency due to beneficial micro-organisms (BM) and combined function for increased digestibility of concentrate mixture and fodder in lactating buffaloes (Gujjar et al., 2006).

\section{Blood parameters: \\ Biochemicals in blood serum:}

During pre-partum period, results presented in Table (5) show that concentrations of blood biochemicals including total protein (TP), albumin (AL), globulin (GL), creatinine, urea-N and glucose in serum of cows were not significantly affected by dietary probiotics supplementation. However, during lactation period (post-partum), concentration of $\mathrm{AL}$ in serum was significantly $(\mathrm{P}<0.05)$ increased, while GL concentration insignificantly decreased in both treatment groups as compared to the control group.

In ruminants, concentration of plasma TP can be an index to evaluate nutrients when fed both adequate and low levels of crude proteins (Kumar et al., 1980). Positive correlation between dietary proteins and plasma TP concentration was reported by Bush (1989). In agreement with the present results, Ibrahim (2004) found that YC supplementation showed insignificant effect on TP concentration in plasma of lactating buffalo cows. Fayed (2001) found that blood serum TP was insignificantly increased 
with Yea-Sacc supplementation in sheep and goats. Also, no effect of premix containing Sac. cerevisiae (6x108 cfu/g of premix, Doreau and Jouany, 1998) or YC (Yea-Sacc ${ }^{1026}$, Iwanska et al., 1999) on TP concentration in plasma lactating cows.

Regarding the level of TP fraction, El-Ashry et al. (2001a) indicated that YS (Yea-Sacc ${ }^{1026}$, Lacto-Sacc and bakery yeast) significantly increased AL concentration in lactating buffaloes. Farag (2004) found YC supplementation decreased concentration of GL in blood serum of buffalo calves, while average concentration of blood AL slightly increased. On the other hand, YC supplementation increased TP concentration of lactating buffaloes (Ibrahim, 2004; Salem et al., 2002) and lambs (El-Shaer, 2003), while $\mathrm{AL}$ and GL levels in blood were not affected by YC supplementation in lactating buffaloes (Ibrahim, 2004) and sheep (El-Shaer, 2003). However, YC supplementation significantly decreased plasma AL concentration in growing buffalo-calves (El-Ashry et al., 2001b) and in Friesian calves fed dietary LactoSacc (Ragheb et al., 2003).

Concerning the effect of YC on blood glucose, some authors reported that glucose concentration in blood was slightly improved in dairy cows and buffalo cows fed rations containing YC (Ahmed, 2001; Ragheb et al., 2003) or lactating cows fed DFM in lactating cows, Iwanska et al. (1999) also reported insignificant differences in blood glucose level as affected by YC (Sac. cereivisiae $\left.{ }^{1026}\right)$ with or without a vitamin premix and mineral bioplexs. In sheep fed YC diet, El-Shaer (2003) indicated no significant effect of YC on glucose concentration. On the other hand, concentration of serum glucose was increased $(\mathrm{P}<0.05)$ by increasing level of $\mathrm{YC}$ supplementation in the diets of lactating Friesian cows (Ahmed, 2001), in Friesian calves fed diet supplemented with Lacto-Sacc (Ragheb et al., 2003) and in lactating buffaloes fed ration supplemented with Yea-Sacc, Lacto-Sacc and backer's yeast (ElAshry et al., 2001a). Finally, Strusinska et al. (2003) found a positive influence of added yeast cultures, mineral and vitamin supplements on selected biochemical indicators in the blood of dairy cows.

\section{Enzymatic activity and hormonal profile:}

Results presented in Table (6) show that activities of transaminases (AST and ALT) and alkaline phosphatase (ALP) were not significantly affected by dietary supplementation of probiotics during pre- and post-partum periods. However, significant $(\mathrm{P}<0.0)$ reduction in concentration of thyroid hormone $\left(\mathrm{T}_{4}\right)$ was observed only in AVI-BAC group as compared to the control group during pre-partum. Also, significant $(\mathrm{P}<0.05)$ reduction was observed in $\mathrm{T}_{3}$ and $\mathrm{T}_{4}$ in both treatment groups as compared to the control group during post-partum period.

The determined values of AST and ALT activities are within the physiological limits of transaminases. According to Pechová et al. (2002), the activity of AST increases in dairy cows suffering from liver steatosis or in cows with disturbed energy metabolism. Its value is therefore very individually variable. Similarly, the activity of ALP enzyme in the blood serum did not exceed the reference volume and was apparently not affected by the addition of probiotics. In agreement with the present results of AVI-Back group, Sretenović1 et al. (2008) reported unaffected activity of AST and ALT in blood of dairy Holstein-Friesian cows. In spite of significant differences in the individual blood indicators, their concentrations are apparently not connected with YC supplementation but rather with the diet and with the individuality of cows.

Table 6. Effect of dietary supplementation of probiotics $(\mathrm{X} \pm \mathrm{S} . \mathrm{E})$ on activity of some enzymes and hormones in blood serum of cows during pre- and post-partum periods

\begin{tabular}{lccc}
\hline \multicolumn{1}{c}{ Item } & Control & AVI-BAC & BGY35 \\
\hline During pre-partum period: & & & \\
AST (U/ml) & $15.66 \pm 0.667$ & $23.33 \pm 4.410$ & $20.33 \pm 3.180$ \\
ALT (U/ml) & $14.33 \pm 0.296$ & $14.60 \pm 0.351$ & $14.26 \pm 0.260$ \\
ALP (IU/l) & $20.99 \pm 6.491$ & $38.95 \pm 21.008$ & $35.46 \pm 10.601$ \\
$\mathrm{~T}_{3}(\mathrm{nmol} / \mathrm{l})$ & $1.83 \pm 0.149$ & $1.53 \pm 0.336$ & $1.99 \pm 0.640$ \\
$\mathrm{~T}_{4}(\mathrm{nmol} / \mathrm{l})$ & $42.54 \pm 4.911^{\mathrm{a}}$ & $25.70 \pm 2.270^{\mathrm{b}}$ & $40.50 \pm 2.522^{\mathrm{a}}$ \\
During post-partum period: & & & \\
$\mathrm{AST}(\mathrm{U} / \mathrm{ml})$ & $14.60 \pm 0.360$ & $14.93 \pm 0.145$ & $15.23 \pm 0.176$ \\
$\mathrm{ALT}(\mathrm{U} / \mathrm{ml})$ & $14.23 \pm 0.176$ & $14.40 \pm 0.265$ & $14.46 \pm 0.384$ \\
$\mathrm{ALP}(\mathrm{IU} / \mathrm{l})$ & $16.79 \pm 0.530$ & $8.59 \pm 2.507$ & $8.22 \pm 1.989$ \\
$\mathrm{~T}_{3}(\mathrm{nmol} / \mathrm{l})$ & $2.16 \pm 0.135^{\mathrm{a}}$ & $1.46 \pm 0.163^{\mathrm{b}}$ & $1.31 \pm 0.098^{\mathrm{b}}$ \\
$\mathrm{T}_{4}(\mathrm{nmol} / \mathrm{l})$ & $84.73 \pm 2.894^{\mathrm{a}}$ & $40.36 \pm 3.543^{\mathrm{b}}$ & $46.16 \pm 6.832^{\mathrm{b}}$ \\
\hline
\end{tabular}

$\mathrm{a}$ and $\mathrm{b}$ : Means having different superscripts within the same row are significantly different at $\mathrm{P}<0.05$.

Table 7. Effect of dietary supplementation of probiotics $(\mathrm{X} \pm \mathrm{S} . \mathrm{E})$ on reproductive performance of cows

\begin{tabular}{lccc}
\hline \multicolumn{1}{c}{ Item } & Control & AVI-BAC & BGY35 \\
\hline Reproductive measurements: & & & \\
PPFSI, day & $91.00 \pm 3.81$ & $68.5 \pm 21.79$ & $66.00 \pm 9.21$ \\
NSC & $2.5 \pm 0.42$ & $2.00 \pm 0.00$ & $1.75 \pm 0.31$ \\
DO & $118.00 \pm 19.41$ & $97.00 \pm 22.51$ & $81.5 \pm 11.623$ \\
Conception rate (\%) & 50 & 50 & 100 \\
\hline
\end{tabular}


Table 8. Effect of dietary supplementation of probiotics $(\mathrm{X} \pm \mathrm{S} . \mathrm{E})$ on progesterone and estradiol in blood serum of cows during pre- and post-partum periods

\begin{tabular}{lccc}
\hline \multicolumn{1}{c}{ Item } & Control & AVI-BAC & BGY35 (G3) \\
\hline During pre-partum period: & & & \\
Progesterone (ng/ml) & $18.997 \pm 3.454$ & $10.133 \pm 4.499$ & $21.109 \pm 5.180$ \\
Estradiol (pg/ml) & $4.664 \pm 0.751$ & $4.881 \pm 0.591$ & $6.239 \pm 1.214$ \\
During post-partum period: & & & \\
Progesterone (ng/ml) & $1.480 \pm 0.194$ & $1.702 \pm 0.173$ & $1.732 \pm 0.194$ \\
Estradiol (pg/ml) & $0.989 \pm 0.215$ & $0.928 \pm 0.079$ & $1.563 \pm 0.368$ \\
\hline
\end{tabular}

All differences among groups are not significant.

Table 9. Effect of dietary supplementation of probiotics $(\mathrm{X} \pm \mathrm{S}$.E) on physiological response of cows during pre- and post-partum periods

\begin{tabular}{lccc}
\multicolumn{1}{c}{ Item } & Control (G1) & AVI-BAC & BGY35 \\
\hline During pre-partum period: & & & \\
Respiration rate $($ times/min) & $27.25 \pm 2.926$ & $26.00 \pm 2.273$ & $24.75 \pm 1.315$ \\
Rectal temperature $\left({ }^{\circ} \mathrm{C}\right)$ & $39.27 \pm 0.229$ & $38.90 \pm 0.367$ & $38.92 \pm 0.368$ \\
Pulse rate (times/min) & $70.50 \pm 6.344$ & $64.25 \pm 3.276$ & $70.40 \pm 4.113$ \\
During post-partum period: & & & \\
Respiration rate $($ times/min) & $26.50 \pm 1.258$ & $26.25 \pm 2.926$ & $26.00 \pm 0.816$ \\
Rectal temperature $\left({ }^{\circ} \mathrm{C}\right)$ & $38.82 \pm 0.249$ & $38.77 \pm 0.165$ & $38.75 \pm 0.126$ \\
Pulse rate (times/min) & $84.00 \pm 1.826$ & $76.25 \pm 4.768$ & $78.50 \pm 0.957$ \\
\hline
\end{tabular}

All differences among groups are not significant.

\section{Reproductive performance:}

Results regarding the reproductive performance of cows in different experimental groups show that postpartum first service interval (PPFSI) was earlier by about 22.5 and $25 \mathrm{~d}$, number of services per (NSC) was less by about 0.5 and 0.75 and days open (DO) was shorter by about 21.0 and $36.5 \mathrm{~d}$ of cows in AVI-BAC and BGY groups than those of the control cows, respectively (Table 7). On the other hand, conception rate was higher in BGY $(100 \%)$ than in AV-BAC groups (50\% in each).

These results indicated that feeding lactating cows on diets supplemented with YC (BGY 35) had beneficial effects on reproductive performance of lactating cows as compared to AVI-BAC did. It is of interest to note that dietary supplementation of YC (BGY 35) markedly increased concentration of progesterone and estradiol in blood serum of cows in BGY group during pre- and post-partum periods as compared to AVI-BAC and control groups, but the differences were not significant (Table 8). Previous studies have identified a strong relationship between the extent of negative energy balance (NEB) in early lactation and decreased conception rate (Butler and Smith, 1989), which may indicate improving energy balance of cows fed both supplements, reflecting increase in reproductive performance of treated cows as compared to the controls

In accordance with the present results, AbdelKhalek, 2003) found that Yea-Sacc (Saccharomyces cerevisiae) supplementation as YC fed to multiparous Friesian cows improved PPFSI, DO, service period and NSC, but the differences were not significant. Also, Dann et al. (2000) observed that days to first breeding (PPFSI) averaged 74.9 and was not affected by YC (Saccharomyces cerevisiae) treatment. Treatment also did not affect services per pregnancy, which averaged 2.1 services. The tendency of improvement in reproductive performance of supplemented cows, in particular with BGY 35, may be related to mineral content of YC. The potential for minerals to play a significant role in cow fertility is indisputable. Reproductive problems are frequently reported in association with trace mineral deficiencies (Boland, 2002). Zinc deficiency in ruminant may be impairing conception rate and ovarian function. The $\mathrm{YC}$ acts as a highly concentrated form of $\mathrm{Zn}$ in which the element is correlated to components in the yeast cells. This may lead to an improvement in reproductive performance when dairy cows were fed YC (Williams, 1988).

\section{Physiological response:}

Physiological response of cows to treatments was expressed as changes in respiration rate (RR), rectal temperature (RT) and pulse rate (PR) as shown in Table (9) as well as amount of consumed water as presented in Table 10 in comparison with the control group. Results in Table (9) show that dietary supplementation of AVI-BAC and BGY resulted in a slight reduction in respiration rate (RR), rectal temperature (RT) and pulse rate of cows during preand post-partum periods as compared to unsupplemted diet (Control group), but the differences were not significant.

As a result of decreasing RR, RT and PR, water consumption of cows in AVI-BAC and BGY groups showed marked decrease as compared to the control group, but the differences were significant $(\mathrm{P}<0.05)$ only between cows in AVI-BAC and control group (Table 10). The observed increase in water consumption of the control cows was mainly due to increasing RR and RT and consequently water loss to regulate body temperature. These findings may indicate beneficial effect of feeding lactating cows on diets supplemented with probiotics to eliminate heat stress during summer season in Egypt. 
Table 10. Effect of dietary supplementation of probiotics $(\mathrm{X} \pm \mathrm{S}$.E) on water consumption of cows during pre- and post-partum periods

\begin{tabular}{lccc}
\hline Water intake & Control & AVI-BAC & BGY35 \\
\hline During pre-partum period: & & & \\
Total water intake (1/h/d) & $46.75 \pm 2.323^{\mathrm{a}}$ & $32.25 \pm 3.425^{\mathrm{b}}$ & $40.00 \pm 2.915^{\mathrm{ab}}$ \\
As ml/kg LBW & $97.77 \pm 5.840^{\mathrm{a}}$ & $67.89 \pm 2.373^{\mathrm{b}}$ & $86.20 \pm 8.716^{\mathrm{ab}}$ \\
As ml/kg W & $456.64 \pm 23.468^{\mathrm{a}}$ & $316.38 \pm 16.665^{\mathrm{b}}$ & $399.97 \pm 37.600^{\mathrm{ab}}$ \\
As ml/ g DM intake & $5.225 \pm 0.258^{\mathrm{a}}$ & $3.58 \pm 0.380^{\mathrm{b}}$ & $4.44 \pm 0.320^{\mathrm{ab}}$ \\
During post-partum period: & & & \\
Total water intake (1/h/d) & $53.25 \pm 3.258^{\mathrm{a}}$ & $41.50 \pm 2.174^{\mathrm{b}}$ & $48.75 \pm 2.831^{\mathrm{ab}}$ \\
As ml/kg LBW & $118.51 \pm 5.563^{\mathrm{a}}$ & $94.33 \pm 2.922^{\mathrm{b}}$ & $111.24 \pm 7.997^{\mathrm{a}}$ \\
As ml/kg W & 54.75 & $435.66 \pm 14.883^{\mathrm{b}}$ & $512.73 \pm 33.892^{\mathrm{a}}$ \\
As ml/ g DM intake & $5.34 \pm 0.386^{\mathrm{a}}$ & $4.13 \pm 0.274^{\mathrm{b}}$ & $4.85 \pm 0.250^{\mathrm{a}}$ \\
\hline
\end{tabular}

$\mathrm{a}$ and $\mathrm{b}$ : Means having different superscripts within the same row are significantly different at $\mathrm{P}<0.05$.

Generally, it was suggested that several factors affect the response of dairy cows to supplemental YC, such as stage of lactation, type of forage fed, feeding strategy, and the forage-to-concentrate ratio (Piva et al., 1993). The efficiency of YC depends among other factors also on the conditions of cultivation, on the concentration of live yeast cells (CFU) as well as on the dose of the culture used (Doležal et al. 2011). Uses and benefits of probiotics were mentioned by Sainsbury (1992) as follows: (1) there is a proven ability to promote growth and productivity in livestock in a perfectly natural way. (2) Probiotics protect against Salmonella infections, including the worst types such as enteritidis and typhimurium. (3) They can protect against toxins produced by harmful forms of E. Coli. (4) Probiotics stimulate immunity to infections by boosting interferon production, immunoglobulin concentration and macrophage activity. (5) They have an activity suppressing Clostridial infection, often associated with intensive livestock production. (6) Probiotics have also been shown to be antagonistic to many other harmful bacteria, such as Klebsiella, Proteus and Campylobacter. (7) There is research evidence that Probiotics are active against the development of cancers in animals.

In addition, the beneficial effect of probiotics could be produced in two ways. They could operate by: (1) Suppressing harmful bacteria; this could manifest itself in reduced numbers of bacteria or in a decreased concentration of harmful metabolites such as enterotoxin. (2) Stimulation of bacteria which are engaged in beneficial activities such as production of essential nutrients like vitamins or in digestion of food components (Mulder, 1991). Increasing levels of probiotics may induce a "barrier" influence against common pathogens. Mechanism of the effect are likely to include the excretion of acids (lactate, acetate), competition for nutrients and gut receptor sites, immunomodulation and the formation of specific antimicrobial agents. Probiotics suppress enzymes responsible for genotoxin formation (Fooks and Gibson, 2002). Soluble products present in yeast culture have been shown to inhibit microbial growth and activity and modulate the immune system (Jensen et al., 2007). Yeast cells also improve digestibility and absorption of minerals such as phosphorus, magnesium, calcium, copper, potassium, zinc and manganese (Kinal et al., 2007).

Based on the foregoing results, dietary supplementation of probiotics as yeast culture, $S$. cerevisiae (20 g BGY $35 / \mathrm{h} / \mathrm{d}$ ) or as a product of lactic acid bacteria and enzymes (3 g AVI-BAC ${ }^{\circledR} / \mathrm{h} / \mathrm{d}$ ), during 2 months pre-partum and 4 months postpartum, improved productive and reproductive performances of lactating cows. Bacterial additive (AVI-BAC) seemed to have a beneficial effect on milk yield and fat yield, while yeast culture (BGY 35) seemed to have pronounced improvement on reproductive performance of dairy cows in terms of increasing conception rate and shortening days open.

\section{REFERENCES}

Abdel-Khalek, A. E., 2003. Productive and reproductive performance of primiparous and multiparous Friesian cows fed rations supplemented with yeast culture (Yea-Sacc ${ }^{1026}$ ). Egyptian J. Nutrition and Feeds 6 (special Issue): 1095-1105.

Ahmed, Sayeda, M.M., 2001. Effect of yeast culture supplementation on nutrients digestibility, some ruminal and blood parameters, milk production of lactating Friesian cows. Second International Conference on Animal Production and Health in Semi-Arid Areas. 195-203.

Ahmed, M.E.; E.I. Shehata,; F.F. Abou Ammou,; A.M. Abdel-Gowad, and K.M. Aiad, 2008. Milk production, feed conversion rate and reproduction of Zaraibi goat in response to bacterial feed additive during late pregnancy and lactation. Egyptain. Journal of Animal Production, 45: 189203.

Aikman, P.C.; P.H. Henning; A.K. Jones,; S. Potteron,; J. Siviter; S. Carter; S. Hill; P. Kirton, and R. Szoka, 2008. Effect of administration of Megasphaera elsdenii NCIMB 41125 lactate utilizing bacteria in early lactation on the production, health and rumen environment of highly productive dairy cows fed a high concentrate diet. KK Animal Nutrition Internal Report. 
AOAC, 1980. Official Methods of Analysis. Association of Official Analytical Chemsists. $13^{\text {th }}$ Ed. Washington, USA.

Bartles, H., M. Bohmer, and C. Heirli, 1972. Serum creatinine determination without protein precipitation. Clinica Chimica Acta, 37: 193-197.

Batzer, F. (1980). Hormonal evaluation of early pregnancy. Fertility and Sterility, 34: 1-13.

Belfield, A. and D.M. Goldberg, 1971. A note on serum nucleotidase determinations. Z. Klin. Chem. U. Klin. Biochem., pp. 197-200.

Boganic, S., R. Lake, J. Place, L. Jones, J. Laycock, G. Carter, and J. Alaghband-Zadeh, 1991. Serum progesterone concentration is raised during early follicular phase in women with polycystic ovaries. Ann. Clin. Biochem., 28:105-106.

Boland, M. P. 2002. A new frontier in trace mineral supplementation. Navigating from Niche Markets to Mainstream. Proceeding of Alltechs, European, Middle Eastern and African Lectutre Tour. Butler and Smith, 1989) Butler, W.R. and Smith, R.D. 1989. Interrelationships between energy balance and postpartum reproductive function in dairy cattle. Journal of Dairy Science, 72:767-783.

Burns, R. 1995. Commercial competitive exclusion bacterial mix ready soon. Feedstuffs, 67 (11): $1450-1456$.

Bush, R. 1989. Performance among different grains expressed by young Holstein calves. Can. Journal of Animal Science, 69: 1099.

Callaway, E. S. and S. A. Martin, 1997. Effects of a Saccharomyces cerevisiae culture on ruminal bacteria that utilize lactate and digest cellulose. Journal of Dairy Science, 80:2035-2044.

Calsamiglia, S., L. Castillejos and M. Busquet, 2006. Alternatives to antimicrobial growth promoters in cattle. In Garnworthy, P C, Wiseman, J: Recent Advances in Animal Nutrition, Nottingham p. 129-167.

Dann, H.M.; J.K. Drackley, G.C. McCoy, M.F. Hutjens and J.E. Garrett, 2000. Effects of yeast culture (Saccharomyces cerevisiae) on prepartum intake and postpartum intake and milk production of Jersey cows. Journal of Dairy Science, 83:123127.

Devegowda, G. 1996. Herbal medicines an untapped treasure in poultry science. Proceding of the World Proultry Science Society II, P.P135-9.

Doležal1, P.; Dvořáček, J.; Doležal1, J.; Čermáková1, J.; Zeman1, L. and Szwedziak, K. 2001. Effect of feeding yeast culture on ruminal fermentation and blood indicators of Holstein dairy cows. Journal Acta Veterinaria Brno, 80: 139-145.

Doreau, M. and J.P. Jouany, 1998. Effect of a Saccharomyces cerevisiae culture on nutrient digestion in lactating dairy cows. Journal of Dairy Science, 81(12): 3214-3221.

Doumas, B.T and Jr. Theodore Peters, 2009. Origins of Dye-Binding Methods for Measuring Serum Albumin. Clinical Chemistry, 55:583-584.

El-Ashry, M.A.; A.M. Kholif, H.A. El-Alamy, and T.A. El-Hamamsy, 2001a. Effect of different yeast cultures supplementation to diet on the productive performance of lactating buffaloes. Egyptian Journal of Nutrition and Feeds, 4: 21.

El-Ashry, M.A.; A. Motagally, Zeba, and Y.A. Maareck, 2001b. Effect of live dried yeast and yeast culture on performance of growing buffalo calves. Egyptian Journal of Nutrition and Feeds, 4(Special Issue): 607.

El-Shaer, E. 2003. Effect of yeast culture supplementation and concentrate: roughage ratio performance of growing lambs. Ph. D. Thesis, Fac. Agric., Mansoura Univ., Egypt.

Farag, Mona, A. 2004. Effect of some growth enhances on animal performance. M. Sc. Thesis, Fac. Agric., Tanta Univ., Egypt.

Fawcett, J.K. and J.E. Scott, 1960. A rapid and precise method for the determination of urea. Journal of Clinical Pathology, 13(2): 156-159.

Fayed, Afaf M., 2001. Effect of using yea-sacc on performance of sheep and goats in Sinai. Egyptian Journal of Nutrition and Feeds, 4: 67.

Fooks, L.J. and G.R. Gibson, 2002. Probiotic as modulators of the gut flora. British Journal of Nutrition, 88 (1 suppl.): $39 \mathrm{~S}-49 \mathrm{~S}$.

Fuller, R., 1989. Probiotics in man and animals. The Journal of applied bacteriology, 66, 365-378, 1989.

Gornal, A.G., C.J. Bardawill, M.M. David, 1949. Determination of serum protein by means of Biuret reaction. J. Biol. Chem. 177: 571-576. Hagg, F.M. and Henning, P.H. 2007. Evaluation of supplementation with Megasphaera elsdenii NCIMB 41125, a lactate utilizing rumen microorganism, on performance in Holstein dairy cows. KK Animal Nutrition Internal Report.

Havenaar, R., H.T. Brink, J.H.H. Huis Veld and R. Fuller, 1992. Selection of strains for probiotics use. In: Probiotics: the Scientific Basis (Ed. Fuller, R.), Chapman and Hail, London, PP. 209224, (C-F. Jin et al. 1997).

Ibrahim, S.E.A., 2004. Physio-nutritional studies on Egyptian buffaloes. Ph. D. Thesis, Fac., Agric., Mansoura University.

Iwanska, S., D. Strusinska, W. Zalewski, and A. Opalka, 1999. The effect of Saccharomyces cerevisiae 1026 used alone or with vitamin mineral premix on milk yield and milk composition in dairy cows. Acta Veterinaria Hungarica, 47(1): 41-52.

Jensen, G.S., A.N. Hart, and A.G. Schauss, 2007. An anti-inflammatory immunogen from yeast culture induces activation and alters chemokine receptor expression on human natural killer cells and B lymphocytes in vitro. Nutrition Research, 27:327335.

Kinal, S., A. Korniewicz, A. Rzasa, D. Korniewicz, K. Bialon and B. Lubojemska, 2007. Effect of Saccharomyces serevisiae yeast metabolites on colostrums quality and passive immunity transfer in calves. Bulletin- Veterinary Institute in Pulawy, 51: 105-108.

Krause, K.M., D.K. Combs and K.A. Beauchemin, 2002. Effects of particle size and grain 
fermentability in midlactation cows.1. Milk production and diet digestibility. Journal of Dairy Science, 85, 1936-1946.

Kumar, N., U.B. Singh and D.N. Verma, 1980. Effect of different levels of dietary protein and energy on growth of male buffalo calves. The Indian journal of animal sciences, 51:513.

Liewendahl, K. 1990. Assessment of thyroid status by laboratory methods: Development and perspectives. Scandinavian Journal of Clinical and Laboratory Investigation, 201: 83-92.

Mulder, R.W.A.W. 1991: Probiotics as a tool against almonella contamination. Misset-World Poultry, 7 (3): 60-68.

Murray, R.L. 1984. Aspartate aminotransferase. in Clinical Chemistry. Theory, analysis and correlation. Kaplan, L.A. and Pesce, A.J. (Ed), CV Mosby Company. pp 1105-1108.

NRC, 1988. Nutrient Requirements of Dairy Cattle. $6^{\text {th }}$ rev. ed. National Research Council (U.S.A.). Subcommittee on Dairy Cattle Nutrition. Washington: National Academy of Sciences.

Pechová, A., J. Illek, and L. Pavlata, 2002. Einwirkungen der Lebersteatose auf den Stoffwechsel bei Milchkühen. Wien Tierärztl Mschr, 89: 325-332.

Piva, G., S. Belladonna, G. Fusconi, and F. Sicbaldi, 1993. Effects of yeast on dairy cow performance, ruminal fermentation, blood components, and milk manufacturing properties. Journal of Dairy Science, 76:2717-2722.

Ragheb, E.E., A.F. Mehrez, and A.E. Abdel-Khalek, 2003. Digestibility coefficient, blood parameters, feed efficiency and growth performance of weaned Friesian calves fed diet supplemented with Lacto-Sacc. Egyptian J. Nutrition and Feeds 6 (special Issue): 693-702.

Robinson, P.H. and J.E. Garrett, 1999. Effect of yeast culture (Saccharomyces cerevisiae) on adaptation of cows to postpartum diets and on lactational performance. Journal of Animal Science, 77:988999.

Sainsbury, D.M.B. 1992. Protecting against stress, probiotic boost natural resistance. Misset-World Poultry, 8 (10): 59-74.

Salem, F.A., S.H. Hassanin and A.A. El-Shewy, 2002. Effect of Saccharomyes cerevisiae supplementation on milk yield and composition, digestibility and some blood constituents in lactating buffaloes. Prod. $1^{\text {st }}$ Ann. Sc. Conf. Anim. and Fish Prod., Mansoura 24 \& 25 Sep., 2002.

SAS, 2002. SAS Institute Inc., Cary, NC, USA. NOTE: SAS Proprietary Software Version 9.00 (TS M0).
Soder, K.J. and L.A. Holden, 1999. Dry matter intake and milk yield and composition of cows fed yeast prepartum and postpartum. Journal of Dairy Science, 82:605-610.

Sretenović, L. j., M.P. Petrović1, S. Aleksić1, V. Pantelić1, V. Katić, V. Bogdanović and R. Beskorovajni, 2008. Influence of yeast, probiotics and enzymes in rations on dairy cows performances during transition. Biotechnology in Animal Husbandry, 24 (5-6): 33-43.

Sterling, L. 1975. Diagnosis and treatment of thyroid disease. Cleveland, CRC Press.

Strusinska, D., S. Iwanska, J. Mierzejewska, A. Skok, 2003. Effect of mineral-vitamin and yeast supplements on concentrations of some bichemical parameters in the blood serum of cows. Medycyna - Weterynaryjna, 59: 323-326.

Swartz, D. L., D. Muller L., G.W. Roger and G. A. Varga, 1994. Effect of yeast cultures on performance of lactating dairy cows: a field study. Journal of Dairy Science, 77:3073-3080.

Trinder, P. 1969. Determination of blood glucose using an oxidaseperoxidase system with a noncarcinogenic chromogen. Journal of Clinical Pathology, 22 (2): 158-161.

Williams, P.E.V., 1988. The action of yeast culture in the rumen feed compounds, 8 (9): 14.

Williams, P.E.V., C.A.G. Tait, G.M. Innes and C.J. Newbold, 1991. Effects of the inclusion of yeast culture (Saccharomyces cerevisiae plus growth medium) in the diet of dairy cows on milk yield and forage degradation and fermentation patterns in the rumen of steers. Journal of Animal Science, 69:3016-3026.

Wohlt, J.E., A.D. Finkelstein and C.H. Chung, 1991. Yeast culture to improve intake, nutrient digestibility, and performance by dairy cattle during early lactation. Journal of Dairy Science, 74:1395-1400.

Wohlt, J.E., T.T. Corcione and P.K. Zajac, 1998. Effects of yeast on feed intake and performance of cows fed diets based on corn silage during early lactation. Journal of Dairy Science, 81:1345-1352.

Yongkai, Li., Chengqun, Yn: Weiyun, Zhu and Tao, Shao. 2012. Effect of complex acid bacteria on silage quality and in vitro dry matter digestibility of corn straw. Journal of Animal and Veterinary Advances, 11 (9): 1395-1399. 


\section{تأثير استخدام بعض الأضافات الغذائية على الأداء الإتتاجى والتناسلى لأبقار اللبن \\ طارق حسن مصطفى، فاروق أمين السيد، محمد إبراهيم أحمد، محمد التابعى الخولانى \\ معه بحوث الإنتاج الحيوانس، مركز البحوث الزراعية، وزارة الزراعة}

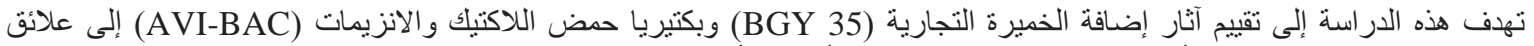





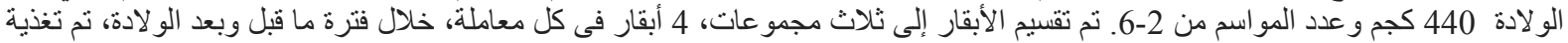

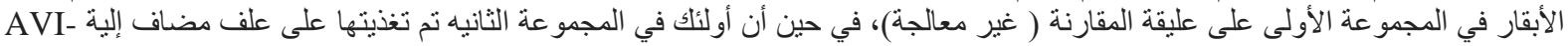



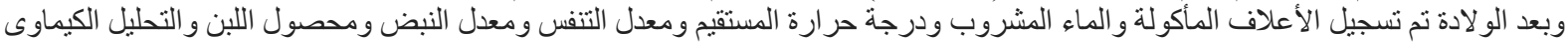

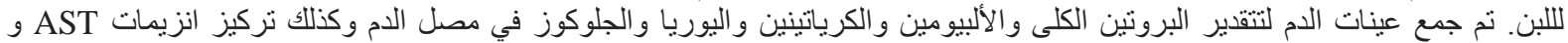

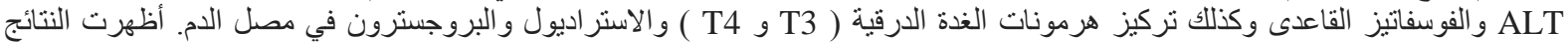



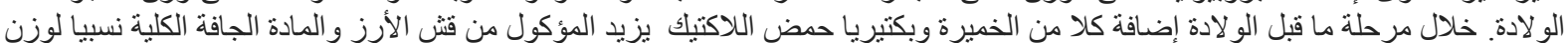





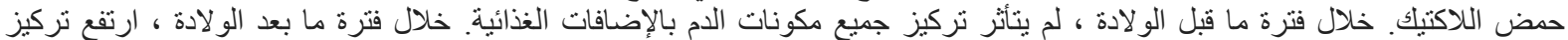



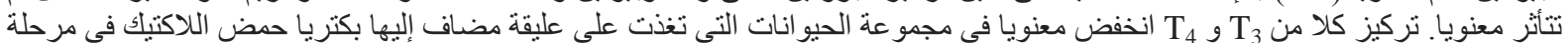

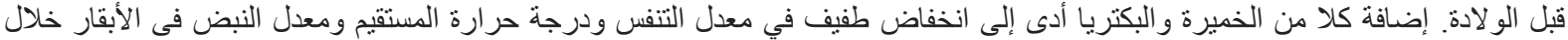

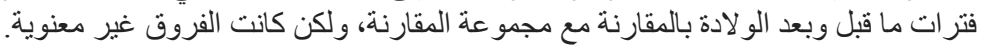

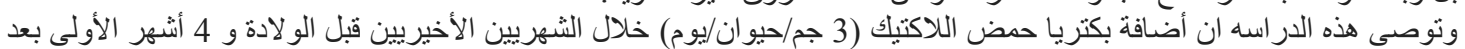

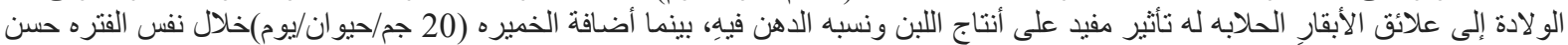

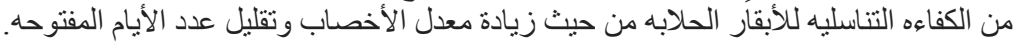

